\title{
Bovine blastocysts with developmental competence to term share similar expression of developmentally important genes although derived from different culture environments
}

\author{
N Ghanem ${ }^{1}$, D Salilew-Wondim, A Gad, D Tesfaye, C Phatsara, E Tholen, C Looft, K Schellander \\ and $M$ Hoelker \\ Animal Breeding and Husbandry Group, Institute of Animal Science, University of Bonn, 53115 Bonn, Germany and \\ ${ }^{1}$ Animal Production Department, Faculty of Agriculture, Cairo University, 12613 Giza, Egypt
}

Correspondence should be addressed to M Hoelker who is now at Department of Animal Breeding and Husbandry, Institute of Animal Science, Endenicher allee 15, 53115 Bonn, Germany; Email: mhoe@itw.uni-bonn.de

N Ghanem and D Salilew-Wondim contributed equally to this work

\begin{abstract}
This study was conducted to investigate the gene expression profile of in vivo-derived bovine embryo biopsies based on pregnancy outcomes after transferring to recipients. For this, biopsies of $\mathbf{3 0}-\mathbf{4 0} \%$ embryos were taken from grade I blastocysts (International Embryo Transfer Society Manual) and the remaining 60-70\% of the intact embryos were transferred to recipients. Frozen biopsies were pooled into three distinct groups based on the pregnancy outcome after transferring the corresponding parts, namely those resulting in no pregnancy (NP), pregnancy loss (PL), and calf delivery (CD). Array analysis revealed a total of 41 and 43 genes to be differentially expressed between biopsies derived from blastocysts resulting in NP versus CD and PL versus CD respectively. Genes regulating placental development and embryo maternal interaction (PLAC8) were found to be upregulated in embryo biopsies that ended up with CD. Embryo biopsies that failed to induce pregnancy were enriched with mitochondrial transcripts (FI405) and stress-related genes (HSPD1). Overall, gene expression profiles of blastocysts resulting in NP and CD shared similar expression profiles with respect to genes playing significant roles in preimplantation development of embryo. Finally, comparing the transcript signatures of in vivo- and in vitro-derived embryos with developmental competence to term revealed a similarity in the relative abundance of 18 genes. Therefore, we were able to present a genetic signature associated with term developmental competence independent of the environmental origin of the transferred blastocysts.

Reproduction (2011) 142 551-564
\end{abstract}

\section{Introduction}

Pregnancy loss $(\mathrm{PL})$ due to early embryonic mortality is considered as a major reproductive problem in all mammalian species. In cattle, early embryonic loss between days 8 and 18 accounts for $\sim 40 \%$ of all PL (Ayalon 1978, Diskin \& Sreenan 1980). Similarly, the vast majority of human embryos cultured in vitro at fertility centers worldwide fail to develop in vivo following transferring to the uterus (Dobson et al. 2004) with implantation rates of only $20 \%$ (Ebner et al. 2001). However, in contrast to the bovine embryos, human embryos were transferred back to the oocyte donors and were transferred to the uterus at earlier stages of development. To date, the underlying molecular mechanisms regulating early embryo loss in both humans and cows are generally unknown. In addition, studies on embryo biology remain ethically challenging in humans. Therefore, other species like cows could be used as an experimental model to understand the molecular mechanisms related to embryonic developmental competence.

The impact of early embryonic mortality is not only a major obstacle to the cattle-breeding industry but also hinders the application of reproductive technologies in mammals such as in vitro embryo production and somatic cell nuclear transfer. Early embryonic mortality is caused by intrinsic defects within the embryo, an inadequate maternal environment, asynchrony between embryo and mother, or failure of the mother to respond appropriately to embryonic signals. However, the extent and regulation of altered gene expression during preimplantation development are likely to be critical for later development of the conceptus (Brison \& Schultz 1997). Using specific culture environments to produce mice or bovine embryos did not only result in altered 
gene expression of transcripts related to metabolism and growth but also resulted in altered conceptus and fetal development following transfer (Khosla et al. 2001, Lazzari et al. 2002).

Many studies examined differences in the expression of developmentally important genes (Rizos et al. 2002, Knijn et al. 2005, Corcoran et al. 2007) or global gene expression profile of in vitro-produced bovine embryos compared with their in vivo counterparts (Smith et al. 2005, 2009, Corcoran et al. 2007). These studies confirmed that there are alterations in gene expression of embryos developed under different culture conditions, which result in reduced quality to be associated with fetal and neonatal abnormalities (Farin et al. 2006) subsequently. Such losses are commonly associated with IVF procedures in human and livestock species of the agriculture industry (Imakawa et al. 2004).

It is assumed that essential mechanisms for embryo implantation must be supported by redundant pathways to ensure the conception of new offspring. Mamo et al. (2006) showed the differences in gene expression profiles of oocytes and embryos that differed in their developmental potential. However, the establishment of direct connections between embryonic gene expression profile and subsequent developmental potential remained challenging. So better knowledge of gene expression patterns and levels during early embryonic development would yield insights into the molecular pathways controlling early development (Khurana \& Niemann 2000) to improve success of embryo culture and, in particular, to develop precise criteria for assessing the health of the early mammalian embryo (Watson et al. 1999).

Recently, we showed that transcriptome analysis of biopsies taken from in vitro-produced bovine blastocysts based on pregnancy outcome after transfer could help to identify transcripts directly related to embryonic developmental potential (El-Sayed et al. 2006). Similarly, we also reported that transcriptome analysis of biopsies taken from in vivo-produced bovine blastocysts could be used as an indicator for further development (Salilew-Wondim et al. 2010). However, direct comparison of both studies is not possible because different array platforms were used to identify differentially regulated genes as well as different synchronization protocols of recipient heifers. Nevertheless, comparing the genetic signatures of in vivo- and in vitro-derived blastocysts with respect to developmental competence, if analyzed by the same techniques and experimental design, could open a new window to understand the molecular mechanisms related to embryonic developmental competence. Therefore, we aimed to extend that work (El-Sayed et al. 2006) with in vivo-derived embryos by using the same techniques and the same experimental design. Consequently, in this study, we aimed to compare the gene expression profile of embryo biopsies taken from in vivoproduced bovine blastocysts depending on the pregnancy outcome after embryo transfer. Finally, our superordinate goal was to compare the signatures of in vivo- and in vitro-derived blastocysts related to term development to identify common signatures closely related to developmental competence.

\section{Results \\ Pregnancy outcomes after embryo transfer}

In the present experiment, 49 in vivo day 7 blastocysts were biopsied. Thirty-eight of these blastocysts (77.7\%) subsequently re-expanded and were transferred to recipients. Of the total recipients that received biopsied and re-expanded blastocysts, $36.8 \%$ (14/38) were classified as non-pregnant, while the remaining $63.1 \%$ (24/38) were classified as pregnant confirmed by ultrasound-guided pregnancy examination performed at day 28 . Nine recipients $(23.6 \%)$ were found to be pregnant at day 28 after estrus but no longer at day 42 , which were classified as PL group. The remaining 15 recipients $(39.5 \%, 15 / 38)$ resulted in calf delivery $(C D)$.

\section{Genes differentially regulated between embryo biopsies resulting in no pregnancy and $C D$}

To obtain a high-confident set of differentially regulated genes, we used a rigorous combination of $P$ values $(P<0.05)$ and false discovery rate (FDR $\leq 5 \%)$. In addition, we set the cut-off value of fold change as $\geq 1.5$. Based on these criteria, 41 genes were found to be differentially expressed. Biopsies corresponding to counterparts resulting in no pregnancy (NP) showed upregulation of 20 transcripts whereas 21 transcripts were found to be downregulated (Fig. 1A).

These differentially expressed genes (Table 1 ) were found to represent genes with known function $(n=30)$ as well as unknown function $(n=11)$. All differentially regulated transcripts were functionally classified based on the criteria of Gene Ontology Consortium classifications (http://www.geneontology.org). The resulting data were supplemented with additional information from various tools available in the National Center for Biotechnology Information (http://www.ncbi.nlm.nih. gov/). Accordingly, certain groups of genes were up- or downregulated in the NP group compared with the CD group: biopsies that ended up with NP were found to be enriched with transcripts related to tumor necrosis factor receptor binding (TNF), protein binding (HSPD1), RNA binding (PA2G4), calcium ion binding (S100A10 and S100A14), and oxidoreductase activity (ND1, FL405, and $A K R 1 B 1)$. Transcripts related to protein binding (KRT8 and ELOVL1), DNA binding (H3F3B and H2FA), structural constituent of ribosome (RPLPO), placenta specific (PLAC8), growth factor activity (bone morphogenetic protein 15 (BMP15)), and signal transducer activity (RGS2) were found to be highly expressed in 
A

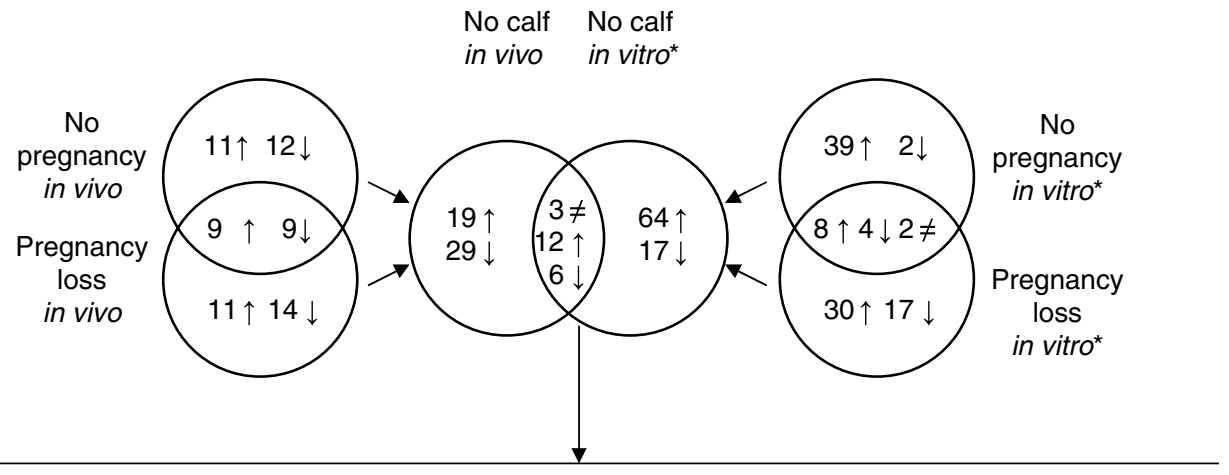

B

\begin{tabular}{|c|c|c|c|c|}
\hline \multirow[b]{2}{*}{ Genes } & \multirow[b]{2}{*}{ Gene function } & \multicolumn{3}{|c|}{ In vivo biopsies } \\
\hline & & $\begin{array}{c}\text { No } \\
\text { pregnancy }\end{array}$ & $\begin{array}{c}\text { Lost } \\
\text { pregnancy }\end{array}$ & No calf \\
\hline PTTG1 & Transcription factors & & $\uparrow$ & $\uparrow$ \\
\hline KRT8 & Protein binding and synth. & $\downarrow$ & $\downarrow$ & $\downarrow$ \\
\hline RPLPO & Protein binding and synth. & $\downarrow$ & $\downarrow$ & $\downarrow$ \\
\hline$R P L 3$ & Protein binding and synth. & & $\uparrow$ & $\uparrow$ \\
\hline RPS15A & Protein binding and synth. & & $\uparrow$ & $\uparrow$ \\
\hline COQ7 & Protein binding and synth. & & $\downarrow$ & $\downarrow$ \\
\hline EEF1A1 & Protein binding and synth. & $\uparrow$ & $\uparrow$ & $\uparrow$ \\
\hline$C D 9$ & Protein binding and synth. & & $\uparrow$ & $\uparrow$ \\
\hline HSPD 1 & Protein binding and synth. & $\uparrow$ & $\uparrow$ & $\uparrow$ \\
\hline H2FAZ & DNA binding & $\downarrow$ & $\downarrow$ & $\downarrow$ \\
\hline BMP15 & Growth factor & $\downarrow$ & $\downarrow$ & $\downarrow$ \\
\hline S100A14 & lon binding & $\uparrow$ & $\uparrow$ & $\uparrow$ \\
\hline$T X N$ & Metabolism/oxidative stress & & $\downarrow$ & $\downarrow$ \\
\hline AKR1B1 & Metabolism/oxidative stress & $\uparrow$ & & $\uparrow$ \\
\hline PTGS2 & Metabolism/oxidative stress & $\downarrow$ & $\downarrow$ & $\downarrow$ \\
\hline PLAC8 & Tissue specific & & $\downarrow$ & $\downarrow$ \\
\hline$T N F$ & Immune response & $\uparrow$ & & $\uparrow$ \\
\hline$F L 405$ & Mitochondrial transcripts & $\uparrow$ & $\uparrow$ & $\uparrow$ \\
\hline$F / 396$ & Mitochondrial transcripts & & $\uparrow$ & $\uparrow$ \\
\hline $\mathrm{NADH}$ & Mitochondrial transcripts & $\uparrow$ & & $\uparrow$ \\
\hline$B 2 M$ & Unknown & $\downarrow$ & & $\downarrow$ \\
\hline
\end{tabular}

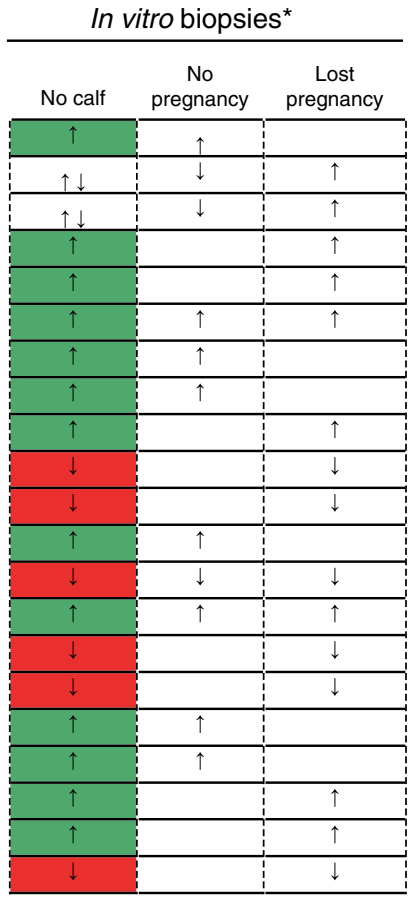

$\downarrow$ : Downregulation of gene relative to biopsies resulting in calf delivery (red shading)

$\uparrow:$ Upregulation of gene relative to biopsies resulting in calf delivery (green shading)

$\neq$ : Gene with none similar expression trend

$*$ : Published previously (EI-Sayed et al. 2006)

Figure 1 Venn diagram showing common differentially expressed genes between no pregnancy, pregnancy loss, and calf delivery both in in vivo- and in vitro-derived embryos (A). List of common genes up- or downregulated in no calf delivery compared with calf delivery group both in in vivo- and in vitro-derived embryos (B).

embryos resulting in CD. RT-qPCR confirmed the expression profile of S100A10, PLAC8, KRT8, BMP15, HSPD1, RGS2, and FL405 to be in agreement with microarray results considering biopsies of NP and CD groups (Fig. 2).

\section{Genes differentially regulated between embryo biopsies resulting in $P L$ and $C D$}

Using criteria of $P$ values $(P<0.05)$ and cutoff fold change $\geq 1.5$, 43 genes were found to be differentially regulated between embryo biopsies resulting in PL (pregnancy at day 28 but resorption until day 42) compared with embryo biopsies resulting in $C D$
(Table 2). In summary, 20 transcripts were upregulated and 23 transcripts were downregulated in biopsies of the PL group compared with biopsies resulting in $\mathrm{CD}$ (Table 2). These transcripts represent genes with known function ( $n=36)$ as well as genes with unknown function $(n=7)$. Based on their functional annotation, genes involved in oxidoreductase activity (FL405 and FL396), structural constituent of ribosome (RPS15A and RPL3), ATPase inhibitor activity (ATPIF1), protein binding (CD9 and HSPD1), calcium ion binding (S100A10), and nucleotide binding (EEF1A1) were upregulated in embryo biopsies resulting in PL. However, biopsies resulting in $\mathrm{CD}$ were enriched with transcripts regulating signal transducer activity (RGS2), cell redox homeostasis 
Table 1 List of genes up- and downregulated in blastocyst biopsies resulting in no pregnancy compared with calf delivery.

\begin{tabular}{|c|c|c|c|}
\hline Gene name & $\begin{array}{c}\text { GenBank } \\
\text { accession no. }\end{array}$ & $\begin{array}{l}\text { Fold } \\
\text { change }\end{array}$ & $\begin{array}{l}\text { Gene function } \\
\text { (biological process) }\end{array}$ \\
\hline \multicolumn{4}{|c|}{ Genes upregulated in blastocyst biopsies resulting in no pregnancy compared with calf delivery $(n=20)$} \\
\hline Homo sapiens S100 calcium-binding protein A14 (S100A14), mRNA & NM_020672 & 2.7 & Calcium ion binding \\
\hline Bos taurus S100 calcium-binding protein A10 mRNA (S100A10) & NM_174650 & 2.4 & Calcium ion binding \\
\hline Homo sapiens S100 calcium-binding protein A16, mRNA (cDNA clone) & BC019099 & 1.6 & Calcium ion binding \\
\hline $\begin{array}{l}\text { Homo sapiens heat-shock } 60 \text { kDa protein } 1 \text { (chaperonin), mRNA (cDNA) } \\
\text { HSPD1 }\end{array}$ & BC002676 & 2.1 & Protein binding (response to stress) \\
\hline Bos taurus clone RP42-351K5, complete sequence & AC092727 & 1.5 & Unknown \\
\hline $\begin{array}{l}\text { Mus musculus cysteine and glycine-rich protein 2, mRNA (cDNA clone) } \\
\text { (CSRP2) }\end{array}$ & BC012663 & 1.6 & Metal ion binding (cell differentiation) \\
\hline Homo sapiens TGFB-induced factor (TALE family homeobox) (TGIF) & NM_003244 & 1.9 & $\begin{array}{l}\text { Transcription factor activity (transcrip- } \\
\text { tion) }\end{array}$ \\
\hline $\begin{array}{l}\text { Homo sapiens proliferation-associated 2G4, } 38 \text { kDa, mRNA (cDNA clone) } \\
\qquad(\text { PA2G4) }\end{array}$ & ВС007561 & 1.5 & RNA binding (cell cycle arrest) \\
\hline $\begin{array}{l}\text { Mus musculus } 11 \text { days embryo gonad cDNA, RIKEN full-length } \\
\quad(7030402 D 04 R i k)\end{array}$ & AK078561 & 1.8 & Unknown \\
\hline Bos taurus EF1A mRNA for elongation factor $1 \alpha$, complete cds (EEF1A1) & AB060107 & 1.7 & Nucleotide binding \\
\hline Homo sapiens RNA-binding motif protein 16 (RBM16), mRNA & XM_376547 & 1.5 & Unknown \\
\hline Homo sapiens TFIIA- $\alpha / \beta$-like factor transcript variant (GTF2A1L) & NM_006872 & 1.8 & $\begin{array}{l}\text { RNA polymerase II transcription factor } \\
\quad \text { (transcription) }\end{array}$ \\
\hline Bovine ATP synthase inhibitor protein mRNA, complete cds (ATPIF1) & M22559 & 2.1 & $\begin{array}{l}\text { ATPase inhibitor (negative regulation of } \\
\text { cellular metabolic) }\end{array}$ \\
\hline Homo sapiens split hand/foot malformation (ectrodactyly) type (SHFM1) & NM_006304 & 1.9 & Peptidase activity (proteolysis) \\
\hline Bos taurus isolate FL405 mitochondrion, partial genome (FL405) & AY308069 & 2.7 & $\begin{array}{l}\text { Oxidoreductase activity (mitochondrial } \\
\text { electron transport) }\end{array}$ \\
\hline Bos taurus isolate $65 \mathrm{NADH}$ dehydrogenase subunit 1 (ND1), NADH & AF490528 & 3.1 & $\begin{array}{l}\text { Oxidoreductase activity (mitochondrial } \\
\text { electron transport) }\end{array}$ \\
\hline $\begin{array}{l}\text { Homo sapiens lectin, galactoside-binding, soluble, } 3 \text { (galectin 3), } \\
\quad(\text { LGALS3) }\end{array}$ & BC001120 & 4.2 & IgE binding \\
\hline $\begin{array}{l}\text { Homo sapiens hypothetical protein LOC57821, mRNA (cDNA clone) } \\
\quad(\text { C1orf114) }\end{array}$ & BC008389 & 2.5 & Unknown \\
\hline Bos indicus tumor necrosis factor- $\alpha$ (TNF) gene, complete cds & AF011927 & 1.8 & $\begin{array}{l}\text { Tumor necrosis factor receptor binding } \\
\text { (immune response) }\end{array}$ \\
\hline Bos taurus AKR1B1 aldo-keto reductase family 1, member B1 & M31463 & 1.9 & $\begin{array}{l}\text { Oxidoreductase activity (oxidation } \\
\text { reduction) }\end{array}$ \\
\hline \multicolumn{4}{|c|}{ Genes downregulated in embryo biopsies resulting in no pregnancy compared with calf delivery $(n=21)$} \\
\hline Homo sapiens placenta-specific 8 (PLAC8), mRNA & NM_016619 & 1.8 & Unknown \\
\hline Bovine mRNA fragment for cytokeratin A (no. 8) (KRT8) & X12877 & 1.5 & $\begin{array}{l}\text { Protein binding (response to other } \\
\text { organism) }\end{array}$ \\
\hline Bovine mRNA for histone H2A.Z (H2FAZ) & X52318 & 1.9 & DNA binding (nucleosome assembly) \\
\hline Homo sapiens $\mathrm{H} 3$ histone, family $3 \mathrm{~A}(H 3 F 3 A)$ & ВТ020962 & 2.5 & DNA binding (nucleosome assembly) \\
\hline Bos taurus mitochondrial RNA, similar to $16 S$ rRNA, clone: ORCS13962 & AB099147 & 3.3 & Unknown \\
\hline Bos taurus BTAB2MDS3 $\beta$ 2-microglobulin (B2M) gene, $3^{\prime}$-UTR & AY325771 & 2.1 & Unknown \\
\hline Ovaries mRNA for thyroid hormone receptor $\beta 1$ & Z68307 & 1.7 & Unknown \\
\hline Homo sapiens tubulin $\alpha 6$, mRNA (cDNA clone MGC:19827 (TUBA1C) & BC011790 & 1.6 & $\begin{array}{l}\text { Nucleotide binding (microtubule-based } \\
\text { movement) }\end{array}$ \\
\hline Homo sapiens mutL homolog 1, colon cancer, non-polyposis type $2(M L H 1)$ & NM_000249 & 2.1 & ATP binding (cell cycle) \\
\hline Homo sapiens elongation of very long chain fatty acids (FEN1/Elo2) (ELOVL1) & NM_022821 & 1.5 & $\begin{array}{l}\text { Protein binding (fatty acid biosynthetic } \\
\text { process) }\end{array}$ \\
\hline Homo sapiens bone morphogenetic protein 15 precursor $(B M P 15)$ gene & AF082350 & 2.4 & $\begin{array}{l}\text { Growth factor activity (female gamete } \\
\text { generation) }\end{array}$ \\
\hline Human DNA sequence from clone RP5-1080B10 on chromosome 20. Contains & AL096769 & 3.3 & Unknown \\
\hline Bos taurus prostaglandin G/H synthase 2 (PTGS2/PGHS2) mRNA, complete cds & AF031698 & 1.7 & $\begin{array}{l}\text { Oxidoreductase activity (electron trans- } \\
\text { port) }\end{array}$ \\
\hline Mus musculus acetylcholinesterase (Ache) and D5Ertd655e genes & AF312033 & 2.2 & $\begin{array}{l}\text { Structural constituent of ribosome (trans- } \\
\text { lation) }\end{array}$ \\
\hline Bos taurus acidic ribosomal phosphoprotein P0 mRNA, partial cds (RPLPO) & AB098748 & 1.8 & Acetylcholinesterase activity \\
\hline Bos taurus vacuolar ATPase subunit F (VATF) mRNA, complete cds & U43176 & 2.3 & $\begin{array}{l}\text { ATP synthase activity, rotational } \\
\text { mechanism (ATP synthesis) }\end{array}$ \\
\hline Homo sapiens KIAA0893 protein, mRNA (cDNA clone MGC:26714) & ВC034964 & 1.9 & Unknown \\
\hline Homo sapiens mRNA for KIAA1052 protein, partial cds (CEP164) & AB028975 & 2.1 & Protein binding \\
\hline Bos taurus zona pellucida glycoprotein 3 (sperm receptor) (ZP3), mRNA & NM_173974 & 1.6 & $\begin{array}{l}\text { Protein binding (binding of sperm to zona } \\
\text { pellucida) }\end{array}$ \\
\hline Homo sapiens regulator of G-protein signaling 2, 24 kDa (RGS2), mRNA & NM_002923 & 2.5 & Signal transducer activity (cell cycle) \\
\hline Rattus norvegicus similar to cofactor required for Sp1 (RGD1560170) & XM_228713 & 2.2 & Unknown \\
\hline
\end{tabular}

Differentially expressed genes were identified by SAM at a false discovery rate (FDR) of $\leq 5 \%$ and $P \leq 0.05$. 


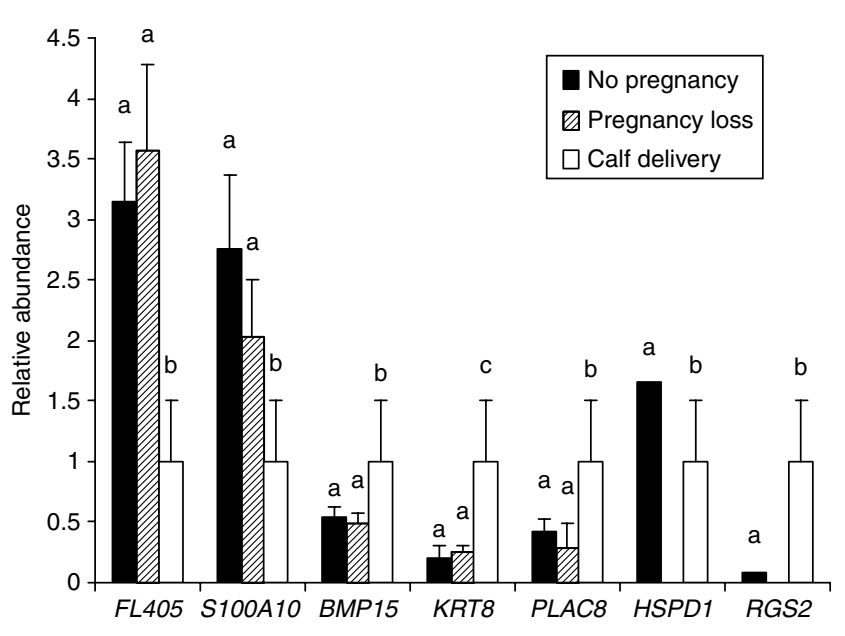

Figure 2 RT-qPCR validation of seven differentially expressed genes between no pregnancy, pregnancy loss, and calf delivery groups. Bars with different superscript letters $(a, b, c)$ indicate significantly different amounts of mRNA within the same gene at $P \leq 0.05$.

$(T X N)$, DNA binding $(H 2 F 2 Z)$, placenta specific (PLAC8), growth factor activity (BMP15), and protein binding (KRT8). From those differentially expressed genes, the expression profile of two upregulated (FL405 and $S 100 A 10)$ and three downregulated genes (BMP15, KRT8, and PLAC8) were validated using RT-qPCR, and the result showed similar expression patterns in both expression-profiling methods (Fig. 2).

\section{Genes differentially regulated between embryo biopsies resulting in aggregate no $C D$ and $C D$}

RT-qPCR validation of three downregulated genes (BMP15, KRT8, and PLAC8) and two upregulated genes (FL405 and S100A10) for NP, PL, and CD groups showed similar values for NP and PL groups without significant differences in relative abundance (Fig. 2). In contrast, relative abundance of all five transcripts was significantly different for $\mathrm{CD}$ group $(P<0.05)$ compared with NP group as well as for PL group (Fig. 2).

Since the biopsies of NP and PL did not result in CD, differentially expressed genes of these two groups were considered as no CD signatures (Tables 3 and 4). Therefore, the pooled results from these groups were compared with the expression profile of embryo biopsies resulting in CD. Accordingly, the results showed 18 genes to be differentially regulated in common in NP and PL groups (Fig. 1A and Table 3). However, 23 genes were identified to be differentially regulated exclusively in the NP group whereas 25 genes were differentially regulated exclusively in the PL group (Table 4). Considering all 66 genes, no gene showed a contradictory trend of gene expression considering NP and PL groups as shown in Tables 3 and 4. Since corresponding biopsies of NP as well as PL did not result in CD, differentially expressed genes of these two groups were therefore combined with an aggregate no CD signature (Tables 3 and 4).

\section{Genes differentially regulated between aggregate no $C D$ and $C D$ for in vitro- and in vivo-derived embryos}

To investigate whether in vivo-derived embryos resulting in $C D$ or no $C D$ could have similar gene expression compared with in vitro-derived embryos of the same developmental competence, we compared the results of this study with those of our previous study focusing on in vitro embryo biopsies (El-Sayed et al. 2006). In both studies, we identified 21 genes (Fig. 1B) that are differentially regulated between biopsies resulting in no $\mathrm{CD}$ compared with $\mathrm{CD}$ for both in vivo- and in vitroderived embryos. Forty-five genes were differentially regulated exclusively for in vivo-derived embryos (19 upregulated and 26 downregulated) and 81 genes were differentially regulated exclusively for in vitro-derived embryos (64 upregulated and 17 downregulated). Of these 21 commonly differently expressed genes between no $C D$ and $C D, 18$ showed the same trend of gene expression for both in vivo- and in vitro-derived embryo signatures (Fig. 1A). Twelve genes were found to be commonly upregulated and six genes were found to be downregulated (Fig. 1A). Only two differentially expressed genes (KRT8 and RPLO) did not show the same trend and only one gene (COQ7) showed a contradictory trend as shown in Fig. 1B.

\section{Discussion}

Analysis of gene expression patterns in early embryos using cDNA microarray provides insight into the function of gene regulatory networks leading to unravel the molecular mechanisms underlying developmental abnormalities (Adjaye et al. 2004). Therefore, we focused on searching for genes that regulate the developmental competence of embryos to term. Hence, similar to our previous study (El-Sayed et al. 2006) focused on in vitro embryo biopsies, in this study, we identified gene expression differences between in vivo-derived blastocysts resulting in $\mathrm{CD}$ and NP or PL. For instance, blastocysts that ended up in NP were enriched with genes related to TNF, protein binding (HSPD1), RNA binding (PA2G4), calcium ion binding (S100A10 and S100A14), and oxidoreductase activity (ND1, FL405, and AKR1B1). Otherwise, transcripts related to protein binding (KRT8 and ELOVL1), DNA binding ( $\mathrm{H} 3 \mathrm{~F} 3 \mathrm{~B}$ and $\mathrm{H} 2 \mathrm{FA})$, structural constituent of ribosome $(R P L P O)$, placenta specific $(P L A C 8)$, growth factor activity (BMP15), and signal transducer activity (RGS2) were found to be downregulated in embryos resulting in NP compared with CD. Biopsies that ended up in PL were found to be enriched with genes involved in oxidoreductase activity (FL405 and FL396), structural constituent of ribosome (RPS15A and RPL3), ATPase inhibitor activity (ATPIF1), protein binding (CD9 and HSPD1), calcium ion binding (S100A10), and nucleotide binding (EEF1A1). Otherwise, transcripts regulating 
Table 2 List of genes up- and downregulated in embryo biopsies resulting in pregnancy loss compared with calf delivery.

\begin{tabular}{|c|c|c|c|}
\hline Gene name & $\begin{array}{c}\text { GenBank } \\
\text { accession no. }\end{array}$ & $\begin{array}{c}\text { Fold } \\
\text { change }\end{array}$ & Gene function (biological process) \\
\hline \multicolumn{4}{|c|}{ Genes upregulated in embryo biopsies resulting in resorption compared with calf delivery $(n=20)$} \\
\hline Bos taurus isolate FL405 mitochondrion, partial genome ( FL405) & AY308069 & 1.9 & $\begin{array}{l}\text { Oxidoreductase activity (mitochondrial } \\
\text { electron transport) }\end{array}$ \\
\hline Bos taurus isolate FL396 mitochondrion, partial genome & AY308068 & 1.7 & $\begin{array}{l}\text { Oxidoreductase activity (mitochondrial } \\
\text { electron transport) }\end{array}$ \\
\hline Homo sapiens pituitary tumor-transforming 1 (PTTG1), mRNA & NM_004219 & 1.5 & Transcription factor activity (transcription) \\
\hline Homo sapiens heat shock 60 kDa protein 1 (chaperonin), (HSPD1) & ВС002676 & 1.7 & Protein binding (response to stress) \\
\hline Bos taurus mRNA for similar to ribosomal protein S15a, partial cds, (RPS15A) & AB099015 & 2.0 & $\begin{array}{l}\text { Structural constituent of ribosome } \\
\text { (translation) }\end{array}$ \\
\hline Bos taurus mRNA for similar to ribosomal protein $\mathrm{L} 3$, partial cds, (RPL3) & AB099068 & 1.6 & $\begin{array}{l}\text { Structural constituent of ribosome } \\
\text { (translation) }\end{array}$ \\
\hline Bos taurus $\mathrm{T}$ cell receptor $\alpha(T C R A)$ gene, J segments and $\mathrm{C}$ region & AY227782 & 3.5 & Unknown \\
\hline Homo sapiens lectin, galactoside-binding, soluble 3, (LGALS3) & BC001120 & 2.1 & IgE binding \\
\hline Bos taurus X-inactivation center region, Jpx and Xist genes & AJ421481 & 1.8 & Unknown \\
\hline Homo sapiens leukocyte receptor cluster (LRC) member 9, mRNA (cDNA) & BC015921 & 1.9 & $\begin{array}{l}\text { Nucleic acid binding (RNA metabolic } \\
\text { process) }\end{array}$ \\
\hline Homo sapiens RNA polymerase II termination factor mRNA, (TTF2) & NM_003594 & 2.1 & DNA binding (transcription) \\
\hline Homo sapiens S100 calcium binding protein A14 (S100A14), mRNA & NM_020672 & 2.0 & Calcium ion binding \\
\hline $\begin{array}{l}\text { Mus musculus cysteine and glycine-rich protein 2, mRNA (cDNA clone) } \\
\text { (CSRP2) }\end{array}$ & BC012663 & 2.5 & Metal ion binding (cell differentiation) \\
\hline Homo sapiens TGFB-induced factor (TALE family homeobox) (TGIF) & NM_003244 & 1.7 & Transcription factor activity (transcription) \\
\hline Homo sapiens B-cell translocation gene 4 (BTG4), mRNA & NM_017589 & 2.0 & (cell cycle arrest) \\
\hline Mus musculus 11 days embryo gonad cDNA, RIKEN full-length (7030402D04Rik) & AK078561 & 2.3 & Unknown \\
\hline Bos taurus EF1A mRNA for elongation factor $1 \alpha$, complete cds (EEF1A1) & AB060107 & 1.5 & Nucleotide binding \\
\hline Bovine ATP synthase inhibitor protein mRNA, complete cds (ATPIF1) & M22559 & 1.9 & $\begin{array}{l}\text { ATPase inhibitor (negative regulation } \\
\text { cellular metabolic) }\end{array}$ \\
\hline Bos taurus S100 calcium-binding protein A10 mRNA (S100A10) & NM_174650 & 2.8 & Calcium ion binding \\
\hline Bos taurus CD9 molecule $(C D 9)$, mRNA & NM_173900 & 1.6 & $\begin{array}{l}\text { Protein binding (negative regulation of } \\
\text { cell proliferation) }\end{array}$ \\
\hline \multicolumn{4}{|c|}{ Genes downregulated in embryo biopsies resulting in resorption compared with calf delivery $(n=23)$} \\
\hline Homo sapiens estrogen-related receptor $\gamma$, mRNA (cDNA clone) (ESRRG) & BC064700 & 2.8 & $\begin{array}{l}\text { Protein binding (positive regulation of } \\
\text { transcription) }\end{array}$ \\
\hline Homo sapiens regulator of G-protein signaling 2, $24 \mathrm{kDa}(R G S 2), \mathrm{mRNA}$ & NM 002923 & 2.3 & Signal transducer activity (cell cycle) \\
\hline Bos taurus $\beta$-actin $(A C T B)$ mRNA, complete cds & AY141970 & 1.8 & Nucleotide binding \\
\hline Bovine mRNA fragment for cytokeratin $\mathrm{A}$ (no. 8) (KRT8) & $\mathrm{X} 12877$ & 3.7 & $\begin{array}{l}\text { Protein binding (response to other } \\
\text { organism) }\end{array}$ \\
\hline Bovine mRNA for histone H2A.Z (H2FAZ) & X52318 & 2.5 & DNA binding (nucleosome assembly) \\
\hline Bos taurus histone $\mathrm{H} 4.1 \mathrm{mRNA}$, complete cds $(\mathrm{H} 4)$ & AF001288 & 1.5 & DNA binding (nucleosome assembly) \\
\hline Bos taurus mRNA for similar to ribosomal protein L18a, partial cds (RPL18a) & AB098916 & 1.6 & $\begin{array}{l}\text { Structural constituent of ribosome } \\
\text { (translation) }\end{array}$ \\
\hline Homo sapiens mitochondrial ribosomal protein L33 (MRPL33), nuclear & NM_004891 & 1.5 & $\begin{array}{l}\text { Structural constituent of ribosome } \\
\text { (translation) }\end{array}$ \\
\hline Homo sapiens elongation of very long chain fatty (ELOVL1) & BC000618 & 1.6 & $\begin{array}{l}\text { Protein binding (fatty acid biosynthetic } \\
\text { process) }\end{array}$ \\
\hline $\begin{array}{l}\text { Homo sapiens coenzyme Q7 homolog, ubiquinone (yeast), mRNA (cDNA) } \\
\text { (COQ7) }\end{array}$ & BC003185 & 1.7 & $\begin{array}{l}\text { Oxidoreductase activity (protein meta- } \\
\text { bolic process) }\end{array}$ \\
\hline Homo sapiens lipoma HMGIC fusion partner-like 3 (LHFPL3), mRNA & NM_199000 & 1.7 & Unknown \\
\hline Homo sapiens zinc finger protein 85 (TFP85), mRNA (cDNA clone) & BC047646 & 2.1 & Transcription factor activity (transcription) \\
\hline Homo sapiens testis mitotic checkpoint BUB3 (BUB3) mRNA, complete cds & AF047473 & 1.5 & $\begin{array}{l}\text { Protein binding (mitotic cell cycle spindle } \\
\text { assembly) }\end{array}$ \\
\hline Bos taurus thioredoxin mRNA, complete cds $(T X N)$ & AF104105 & 2.4 & (cell redox homeostasis) \\
\hline Homo sapiens NANOS1 mRNA, complete cds & AF275269 & 1.9 & RNA binding (regulation of translation) \\
\hline Homo sapiens cyclin B3 (CCNB3), transcript variant 2, mRNA & NM_033671 & 1.7 & (cell cycle) \\
\hline Homo sapiens placenta-specific 8 (PLAC8), mRNA & NM_016619 & 2.0 & Unknown \\
\hline Bos taurus mitochondrial RNA, similar to $16 \mathrm{~S}$ rRNA, clone: ORCS13962 & AB099147 & 1.8 & Unknown \\
\hline Homo sapiens bone morphogenetic protein 15 precursor (BMP15) gene & AF082350 & 2.1 & $\begin{array}{l}\text { Growth factor activity (female gamete } \\
\text { generation) }\end{array}$ \\
\hline Bos taurus acidic ribosomal phosphoprotein PO mRNA, partial cds (RPLPO) & AF013214 & 1.9 & $\begin{array}{l}\text { Structural constituent of ribosome } \\
\text { (translation) }\end{array}$ \\
\hline Homo sapiens aurora kinase $\mathrm{A}(A \cup R K A)$ & ВC027464 & 2.4 & Kinase activity (cell cycle) \\
\hline Oocyte expressed protein homolog (dog) (Homo sapiens) (OOEP) & BC024931 & 2.1 & Unknown \\
\hline Bos taurus prostaglandin $\mathrm{G} / \mathrm{H}$ synthase 2 (PTGS2/PGHS2) mRNA, complete cds & AF031698 & 1.5 & $\begin{array}{l}\text { Oxidoreductase activity (electron } \\
\text { transport) }\end{array}$ \\
\hline
\end{tabular}

Differentially expressed genes were identified by SAM at a false discovery rate (FDR) of $\leq 5 \%$ and $P \leq 0.05$. 
Table 3 Commonly expressed transcripts of biopsies resulting in no pregnancy or pregnancy loss relative to biopsies that resulted in calf delivery.

\begin{tabular}{|c|c|c|c|c|}
\hline \multirow[b]{2}{*}{ Gene } & \multirow[b]{2}{*}{ Gene function } & \multicolumn{3}{|c|}{ In vivo biopsies } \\
\hline & & $\begin{array}{c}\text { No } \\
\text { pregnancy }\end{array}$ & $\begin{array}{l}\text { Pregnancy } \\
\text { loss }\end{array}$ & $\begin{array}{l}\text { No calf } \\
\text { delivery }\end{array}$ \\
\hline ELOVL1 & Protein binding and synth. & $\downarrow$ & $\downarrow$ & $\downarrow$ \\
\hline KRT8 & Protein binding and synth. & $\downarrow$ & $\downarrow$ & $\downarrow$ \\
\hline RPLPO & Protein binding and synth. & $\downarrow$ & $\downarrow$ & $\downarrow$ \\
\hline EEF1A1 & Protein binding and synth. & $\uparrow$ & $\uparrow$ & $\uparrow$ \\
\hline HSPD1 & Protein binding and synth. & $\uparrow$ & $\uparrow$ & $\uparrow$ \\
\hline H2FAZ & DNA binding & $\downarrow$ & $\downarrow$ & $\downarrow$ \\
\hline BMP15 & Growth factor & $\downarrow$ & $\downarrow$ & $\downarrow$ \\
\hline S100A10 & Ion binding & $\uparrow$ & $\uparrow$ & $\uparrow$ \\
\hline S100A14 & lon binding & $\uparrow$ & $\uparrow$ & $\uparrow$ \\
\hline CSRP2 & Ion binding & $\uparrow$ & $\uparrow$ & $\uparrow$ \\
\hline PTGS2 & Metabolism/oxidative stress & $\downarrow$ & $\downarrow$ & $\downarrow$ \\
\hline LGALS3 & Immune response & $\uparrow$ & $\uparrow$ & $\uparrow$ \\
\hline FL405 & Mitochondrial transcripts & $\uparrow$ & $\uparrow$ & $\uparrow$ \\
\hline ATPIF1 & Mitochondrial transcripts & $\uparrow$ & $\uparrow$ & $\uparrow$ \\
\hline RGS2 & Cell cycle & $\downarrow$ & $\downarrow$ & $\downarrow$ \\
\hline ORCS13962 & Unknown & $\downarrow$ & $\downarrow$ & $\downarrow$ \\
\hline RIKEN & Unknown & $\uparrow$ & $\uparrow$ & $\uparrow$ \\
\hline PLAC8 & Unknown & $\downarrow$ & $\downarrow$ & $\downarrow$ \\
\hline
\end{tabular}

signal transducer activity (RGS2), cell redox homeostasis $(T X N)$, DNA binding $(H 2 F 2 Z)$, placenta specific (PLAC8), growth factor activity (BMP15), and protein binding (KRT8) were downregulated in embryos resulting in PL compared with CD.

Interestingly, the signatures of in vivo-derived embryos resulting in NP and PL showed high similarities in our study. The RT-qPCR validation of five selected transcripts (FL405, S100A10, BMP15, KRT8, and PLAC8) showed similar trends and amounts for embryos of NP and PL groups, however, being significantly different compared with the CD group, that is, in great accordance with our previous study dealing with in vitro-derived embryos (El-Sayed et al. 2006). Accordingly, comparison of the expression of 18 genes differentially expressed in NP and $\mathrm{PL}$ groups relative to the $\mathrm{CD}$ group showed the same trend for all 18 genes. Moreover, no contradictory expression trends were observed for 66 genes differentially expressed either for NP or for PL compared with the CD group. For example, embryo biopsies resulting in CD showed upregulation of RGS2 as well as KRT8 compared with both NP and PL groups. RGS2, a regulator of G-protein signaling family member (Zmijewski et al. 2001), has been reported to be involved in regulating the intracellular calcium mobilization and T-cell proliferation at the maternal-fetal interface during embryo implantation (Huang et al. 2003). Higher gene expression has already been reported for bovine zygotes with superior developmental competence (Salilew-Wondim et al. 2007). Keratins like KRT8 are among the first cytoskeleton genes differentially expressed in the trophectoderm (TE) of mouse blastocysts (Brulet et al. 1980, Jackson et al. 1980, Oshima et al. 1983) and mediate cellular proliferation and differentiation during conceptus development (Blomberg et al. 2005). Mice deficient for KRT8 caused embryonic lethality (Baribault et al. 1993) due to loss of contact between maternal and embryonic tissues resulting in early abortion (Hesse et al. 2000). According to the results of this study and that of our previous study (El-Sayed et al. 2006), we suggest that embryos that result in NP or PL are tending to have similar gene expression patterns. Indeed, embryos being viable until day 25 , for example, would have been classified as NP group whereas embryos dying at day 29 would have been classified as PL group due to the fact that first pregnancy check was performed at day 28 in this study. Consequently, we aggregated the signatures of biopsies classified as NP and PL groups to an aggregate no CD signature being contrary to $C D$.

The results of this study were compared with our previous results (El-Sayed et al. 2006) to look into common molecular signatures of in vivo- and in vitroderived embryos related to developmental competence. Accordingly, we identified 21 genes differentially regulated between embryos of no $C D$ and $C D$ groups both in in vivo- and in vitro-derived embryos (Fig. 1). Thus, the results of this study and the previous study (El-Sayed et al. 2006) evidenced that embryos developed under different culture conditions (in vivo and in vitro) have some similarities in their transcript abundances. That observation seems to be contradictory to numerous studies reporting differences in global gene expression profile between in vivo- and in vitro-derived embryos (Smith et al. 2005, 2009, Corcoran et al. 2007) as well as differences in terms of selected developmentally important genes (Rizos et al. 2002, Knijn et al. 2005, Corcoran et al. 2007). In contrast to these studies, however, our study includes subpopulations of embryos with variable developmental competence into account, which might give a more objective picture.

Of these 21 genes, 18 showed the same expression trend for in vivo- and in vitro-derived embryos comparing no $C D$ with $C D$ respectively. For example, $T X N$ was found to be upregulated in biopsies of embryos cultured both in vitro and in vivo resulting in $C D$ compared with those leading to no CD. TXN had been identified as so-called 'early pregnancy factor' (Clarke et al. 1991, Clarke 1992). The biological functions of TXN include activation of some transcription factors, anti-apoptotic function, and proliferation (Hirota et al. 1997, Powis et al. 1997, 1998, Arrigo 1999, Arner \& Holmgren 2000). TXN helps the embryo to resist against oxidative stress (Kobayashi-Miura et al. 2002). For instance, supplementation of the culture medium with thioredoxin was found to improve blastocyst formation, cell numbers, and incidence of apoptosis of in vitroproduced embryos of pigs (Ozawa et al. 2006), cattle (Bing et al. 2003), and mice (Nonogaki et al. 1991). Lopata et al. (2001) demonstrated the importance of 
Table 4 Transcripts not commonly expressed in biopsies resulting in no pregnancy or pregnancy loss relative to biopsies that resulted in calf delivery.

\begin{tabular}{|c|c|c|c|c|}
\hline \multirow[b]{2}{*}{ Gene } & \multirow[b]{2}{*}{ Gene function } & \multicolumn{3}{|c|}{ In vivo biopsies } \\
\hline & & $\begin{array}{c}\text { No } \\
\text { pregnancy }\end{array}$ & $\begin{array}{c}\text { Pregnancy } \\
\text { loss }\end{array}$ & $\begin{array}{l}\text { No calf } \\
\text { delivery }\end{array}$ \\
\hline PTTG1 & Transcription factors & & $\uparrow$ & $\uparrow$ \\
\hline TGIF & Transcription factors & $\uparrow$ & & $\uparrow$ \\
\hline GTF2A1L & Transcription factors & $\uparrow$ & & $\uparrow$ \\
\hline TPF85 & Transcription factors & & $\downarrow$ & $\downarrow$ \\
\hline CEP164 & Protein binding and synth. & $\downarrow$ & & $\downarrow$ \\
\hline ZP3 & Protein binding and synth. & $\downarrow$ & & $\downarrow$ \\
\hline ESRRG & Protein binding and synth. & & $\downarrow$ & $\downarrow$ \\
\hline RPL18a & Protein binding and synth. & & $\downarrow$ & $\downarrow$ \\
\hline MRPL33 & Protein binding and synth. & & $\downarrow$ & $\downarrow$ \\
\hline$B \cup B 3$ & Protein binding and synth. & & $\downarrow$ & $\downarrow$ \\
\hline RPL3 & Protein binding and synth. & & $\uparrow$ & $\uparrow$ \\
\hline RPS15A & Protein binding and synth. & & $\uparrow$ & $\uparrow$ \\
\hline COQ7 & Protein binding and synth. & & $\downarrow$ & $\downarrow$ \\
\hline CD9 & Protein binding and synth. & & $\uparrow$ & $\uparrow$ \\
\hline TUBA1C & Nucleotide binding & $\downarrow$ & & $\downarrow$ \\
\hline ACTB & Nucleotide binding & & $\downarrow$ & $\downarrow$ \\
\hline$L R C$ & Nucleotide binding & & $\uparrow$ & $\uparrow$ \\
\hline TTF2 & DNA binding & & $\uparrow$ & $\uparrow$ \\
\hline TGIF & DNA binding & & $\uparrow$ & $\uparrow$ \\
\hline H3F3A & DNA binding & $\downarrow$ & & $\downarrow$ \\
\hline $\mathrm{H} 4$ & DNA binding & & $\downarrow$ & $\downarrow$ \\
\hline PA2G4 & RNA binding & $\uparrow$ & & $\uparrow$ \\
\hline NANOS1 & RNA binding & & $\downarrow$ & $\downarrow$ \\
\hline S100A16 & lon binding & $\uparrow$ & & $\uparrow$ \\
\hline$T X N$ & Metabolism/oxidative stress & & $\downarrow$ & $\downarrow$ \\
\hline$A K R 1 B 1$ & Metabolism/oxidative stress & $\uparrow$ & & $\uparrow$ \\
\hline VATF & ATP synthesis & $\downarrow$ & & $\downarrow$ \\
\hline$T N F$ & Immune response & $\uparrow$ & & $\uparrow$ \\
\hline TCRA & Immune response & & $\uparrow$ & $\uparrow$ \\
\hline FI396 & Mitochondrial transcripts & & $\uparrow$ & $\uparrow$ \\
\hline $\mathrm{NADH}$ & Mitochondrial transcripts & $\uparrow$ & & $\uparrow$ \\
\hline SHFM1 & Peptidase activity & $\uparrow$ & & $\uparrow$ \\
\hline ACHE & Acetylcholinesterase activity & $\downarrow$ & & $\downarrow$ \\
\hline CCNB3 & Cell cycle & & $\downarrow$ & $\downarrow$ \\
\hline AURKA & Cell cycle & & $\downarrow$ & $\downarrow$ \\
\hline BTG4 & Cell cycle & & $\uparrow$ & $\uparrow$ \\
\hline MLH1 & Cell cycle & $\downarrow$ & & $\downarrow$ \\
\hline RP42-351K5 & Unknown & $\uparrow$ & & $\uparrow$ \\
\hline$J P X$ & Unknown & & $\uparrow$ & $\uparrow$ \\
\hline RP5-1080B10 & Unknown & $\downarrow$ & & $\downarrow$ \\
\hline$B 2 M$ & Unknown & $\downarrow$ & & $\downarrow$ \\
\hline C1orf114 & Unknown & $\uparrow$ & & $\uparrow$ \\
\hline OOEP & Unknown & & $\downarrow$ & $\downarrow$ \\
\hline MGC:26714 & Unknown & $\downarrow$ & & $\downarrow$ \\
\hline LHFPL3 & Unknown & & $\downarrow$ & $\downarrow$ \\
\hline RGD1560170 & Unknown & $\downarrow$ & & $\downarrow$ \\
\hline RBM16 & Unknown & $\uparrow$ & & $\uparrow$ \\
\hline THRB1 & Unknown & $\downarrow$ & & $\downarrow$ \\
\hline
\end{tabular}

thioredoxin expression in cytotrophoblast cells during human embryo implantation.

Six genes with the same expression trend for in vivoand in vitro-derived embryos comparing no $\mathrm{CD}$ with $\mathrm{CD}$ groups, respectively, had also identical expression trends for NP and PL groups (HSPD1, H2FAZ, BMP15, PTGS2/PGHS2/COX2, PLAC8, FL405). These genes may be ideal candidates for further functional analysis for the establishment of comprehensive physiological models of early embryonic mortality. For example, heat-shock $60 \mathrm{kDa}$ protein 1 (HSPD1) are among the first proteins produced during embryogenesis (Bensaude et al. 1983, Liu et al. 2004) and their main function is to protect cellular proteins during stress and act by anti-apoptotic action (Betts \& King 2001, Edwards et al. 2001). Heatshock genes prevent apoptosis induced by a variety of stressors including oxidative stress (Yamagishi et al. 2002) and TNF (Soto et al. 2003, Loureiro et al. 2007), which was found to be also upregulated in embryos resulting in no $C D$ in this study. In addition to HSPD1, others including PTGS2/PGHS2/COX2, BMP15, and PLAC8 were also enriched in embryo biopsies resulting in $\mathrm{CD}$. For instance, prostaglandin $\mathrm{G} / \mathrm{H}$ synthase 2 (PTGS2), which was also enriched in biopsies derived from blastocysts resulting in $C D$, is involved in the process of blastocyst implantation and plays important roles in embryo to uterus interaction processes (Snabes \& Harper 1984). Charpigny et al. (1997) showed that PTGS2 protein was localized only in trophoblast cells of ovine embryos. This may suggest that PTGS2/PGHS2/ COX2 is a potential candidate for blastocyst competency. PLAC8 was found to be upregulated in embryo biopsies resulting in $\mathrm{CD}$ in in vitro- and in vivo-derived embryos. That result is in line with several studies (Galaviz-Hernandez et al. 2003, Klein et al. 2006), suggesting that PLAC8 has a potential role for placental development as well as for the embryo maternal interface. BMP15, an important oocyte-derived growth factor that is required for normal folliculogenesis and female fertility of mammals (Juengel et al. 2002), was highly enriched in embryo biopsies that ended up with CD. That is in line with the observation of Wu et al. (2007) who showed that human oocytes from follicles with relatively high BMP15 levels had a better developmental potential than those from follicles with relatively low BMP15 levels. Moreover, mutation of BMP15 has been found to be associated with hypergonadotropic ovarian failure in women (Di Pasquale et al. 2004). Embryo biopsies resulting in $C D$ also over-expressed $H 2 F A Z$, a gene related to histone modification. Aberrations in transcript levels of histone-modifying genes before and after embryonic genome activation had been reported to contribute to the poor quality of cloned embryos (Santos et al. 2003, Nowak-Imialek et al. 2008, Shao et al. 2008).

According to the high signature similarities, we could imagine that in vitro-derived bovine embryos bearing term developmental competence do not differ largely compared with in vivo-derived embryos with term developmental competence. We speculate that differences between embryos of different developmental competence $(C D$ versus no $C D)$ are larger than those between embryos of different sources (in vivo versus in vitro). Whether embryos of both origins with developmental competence to term are similar in an absolute manner or in more a relative manner should be the topic of further studies. Nevertheless, our RT-qPCR validation results as well as the fact that some of the genes present in the commonly expressed signature had been reported 
to be affected by the environment previously (Hoelker et al. 2009) indicate a relative similarity. However, gene expression was only investigated as average for a pool of blastocysts in that study. Whether environment affects gene expression of all embryos similarly or differently for subpopulations of embryos, for example, according to developmental competence, has not been evaluated in that study.

Taken together in the present work, we identified genetic signatures of in vivo-derived embryos correlated with developmental competence to term. Embryos that result in NP or PL were difficult to distinguish with respect to gene expression profile. Moreover, a subpopulation of in vitro-derived blastocysts, namely those with developmental competence to term, expressed a genetic signature similar to that of in vivo-derived embryos with term developmental competence for a set of genes. Further gene expression analysis with larger numbers of genes of in vitro- and in vivo-derived embryos that ended up with similar phenotypes and further functional analysis of these genes will help in the establishment of comprehensive physiological models of early embryonic mortality and will provide the basis to devise new strategies with the aim of enhancing embryonic survival for human and bovine ARTS.

\section{Materials and Methods}

\section{Experimental design}

In vivo-derived blastocysts were flushed from superovulated heifers. After collection, blastocysts were split in two proportions: $\sim 60-70 \%$ of the entire embryos were transferred to synchronized recipients and the remaining $30-40 \%$ were stored frozen until CD. After checking the outcome of the transferred embryos, the corresponding counterparts were pooled into three groups, namely, I) NP, II) PL, and III) CD. These groups were subsequently subjected to gene expression analysis to identify differentially expressed genes related to developmental competence. Gene expression patterns were compared with embryo biopsies (group I versus group III and group II versus group III). An overview of the experimental design is shown in Fig. 3.

\section{In vivo embryo production}

All experimental animals were handled according to the animal protection law of Germany. To collect in vivo-derived blastocysts, Simmental heifers $(n=12)$ of similar age (24 months) were maintained under identical conditions compared with our previous study (El-Sayed et al. 2006). Heifers were synchronized as described by El-Sayed et al. (2006). Briefly, heifers were synchronized by i.m. injection of $500 \mathrm{mg}$ cloprostenol ( $\mathrm{PGF}_{2 \alpha}$, Estrumate; Essex Tierarznei, Munich, Germany) twice within 11 days (Fig. 4). Two days after the administration of $\mathrm{PGF}_{2 \alpha,}$ all animals received $0.02 \mathrm{mg} \mathrm{GNRH}$ (Receptal; Intervet, Boxmeer, The Netherlands). Twelve days after the second GNRH injection, heifers received the first of eight consecutive $\mathrm{FSH}$ injections over 4 days in decreasing doses (in total 300-400 mg FSH according to body weight; University of Liege, Belgium). PGF $_{2 \alpha}$ was administered 72 and $84 \mathrm{~h}$ after the initial FSH injection. Finally, $48 \mathrm{~h}$ after the first administration of $\mathrm{PGF}_{2 \alpha}$, ovulations were induced by injecting $0.02 \mathrm{mg}$ GNRH simultaneously with the first of a total of two artificial inseminations within a $24 \mathrm{~h}$ interval. The first day of insemination was defined as day 0 .

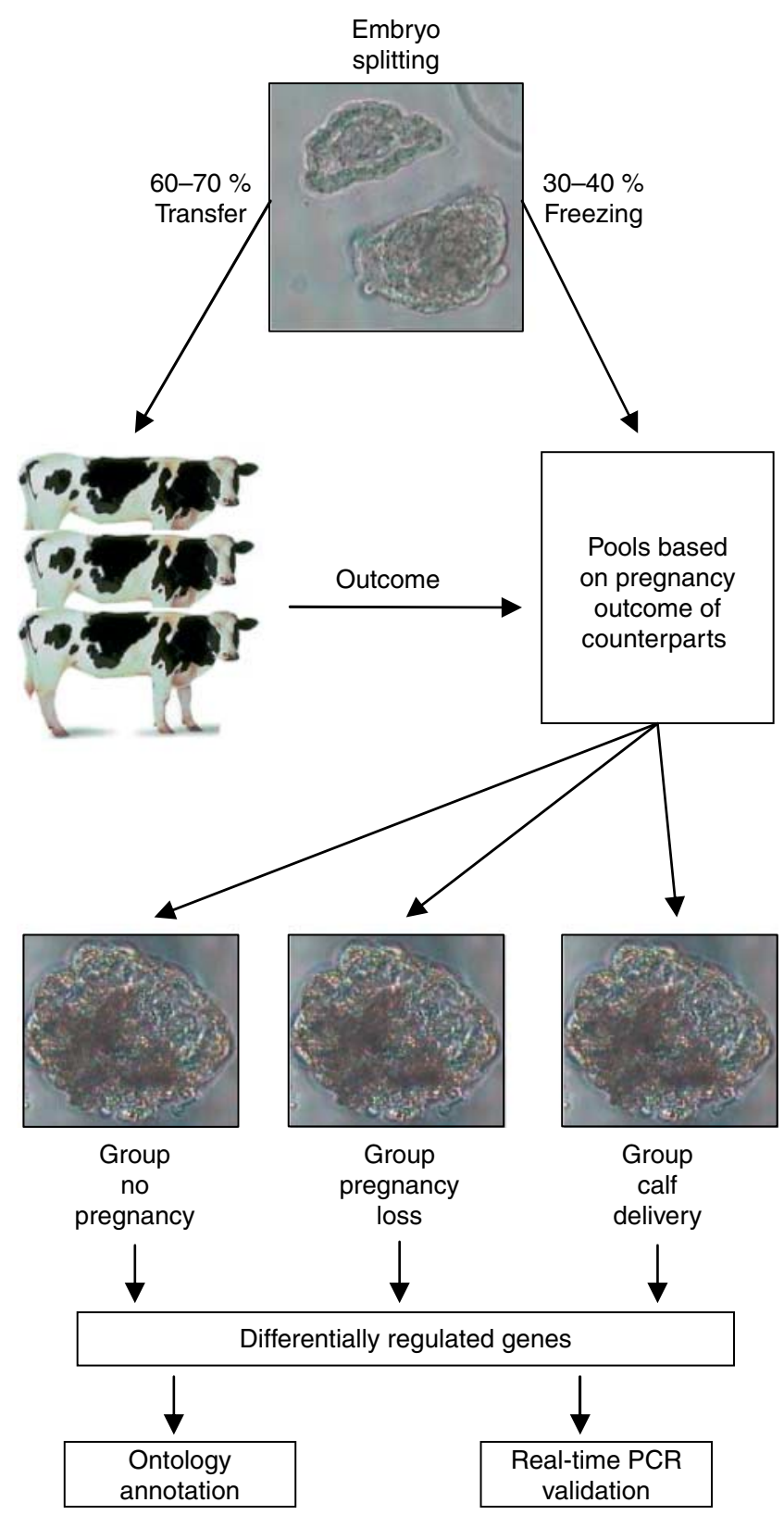

Figure 3 Overview of the overall experiment. Bovine blastocysts were split, the smaller proportions (30-40\%) were stored frozen, and the parts consisting of $60-70 \%$ were transferred to recipients. Following this, the stored embryo biopsies were pooled according to the pregnancy outcome as no pregnancy, pregnancy loss, and calf delivery groups for gene expression analysis. 


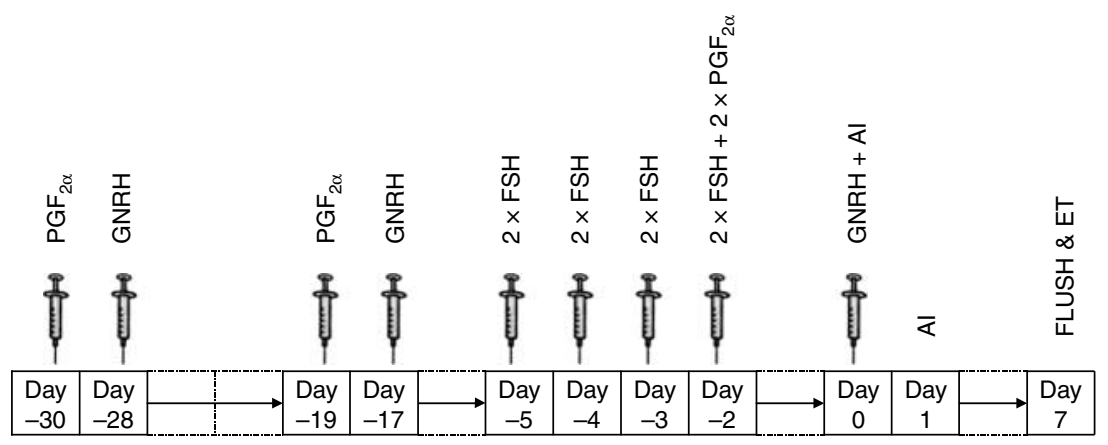

Figure 4 Synchronization of donor animals by intramuscular injection of $\mathrm{PGF}_{2 \alpha}$, twice within 11 days. Two days after administration of $\mathrm{PGF} \mathrm{F}_{2 \alpha}$, all animals received GNRH. Twelve days after the second GNRH injection, heifers received the first of eight consecutive FSH injections over 4 days. $\mathrm{PGF}_{2 \alpha}$ was administered 72 and $84 \mathrm{~h}$ after the initial FSH injection. Finally, $48 \mathrm{~h}$ after the first administration of PGF $2 \alpha$, ovulations were induced by injecting GNRH simultaneously with the first of a total of two artificial inseminations (Al) within a $24 \mathrm{~h}$ interval.

\section{Blastocyst recovery and embryo biopsy}

The blastocysts were collected on day 7 after insemination. Embryo flushing catheter (CH15, Wörrlein, Ansbach, Germany) was fixed in the uterine horn and subsequently embryos were flushed out by draining each uterine horn with $500 \mathrm{ml}$ PBS. All the flushed blastocysts were assessed under a stereo microscope for their quality. Only blastocysts scored as grade I according to the Manual of the International Embryo Transfer Society (IETS) were used for biopsy performed using a Beaver microplate (Minitüb, Tiefenbach, Germany) and were fixed to a micromanipulator under an inverse microscope (Leica Camera, Solms, Germany). In this procedure, 30-40\% of blastocysts containing both inner cell mass and TE cells were taken for biopsy, and the remaining 60-70\% were cultured in vitro for $2 \mathrm{~h}$ to allow re-expansion before transferring to recipients. Only re-expanded biopsied blastocysts were transferred to recipients and the corresponding biopsies were snap frozen in cryo-tubes containing minimal amounts of lysis buffer $(0.8 \%$ Igepal (Sigma), $40 \mathrm{U} / \mathrm{ml} \mathrm{RNasin}$ (Promega), $5 \mathrm{mM}$ dithiothreitol (DTT; Promega)). All frozen biopsies were stored at $-80{ }^{\circ} \mathrm{C}$ until used for RNA isolation and subsequent transcriptome profiling.

\section{Embryo transfer and pregnancy monitoring}

Simmental heifers of similar age (24 months) were used as recipients for embryo transfer. Estrus was synchronized by administration of $\mathrm{PGF}_{2 \alpha}$ (2 $\mathrm{ml}$ Estrumate; Fa. Essex, München, Germany) followed by a second administration 11 days later. Single re-expanded and blastocoel-formed biopsied blastocysts were transferred to recipients by nonsurgical standard procedures at day 7 of the estrous cycle. Following transfer, pregnancy monitoring was done at days 28 and 42 . While those recipients that were not pregnant confirmed by ultrasonography at day 28 were classified as the NP group and those that were pregnant at day 28 but lost their pregnancy between days 28 and 42 were classified as PL group. Embryo biopsies that sustained pregnancy to term and delivering live calves were classified as $\mathrm{CD}$ group.

\section{RNA isolation}

Total RNA was isolated using PicoPure RNA isolation kit (MDS Analytical Technologies $\mathrm{GmbH}$, Ismaning, Germany) according to manufacturer's instructions, and RNA isolation was performed using I) a total of nine pools, therefore three for each category, each containing three embryo biopsies, to be used for array analysis after amplification. II) RNA of these pools was enhanced with the RNA extracted from additional biopsies of the same group, which were not used for array analysis (two biopsies per each of the three pools for CD group, one biopsy per each of the three pools for NP group, and no additional biopsy for PL group) to perform RT-qPCR. Briefly, embryo biopsies using lysis buffer were mixed with $100 \mu$ l extraction buffer and incubated at $42{ }^{\circ} \mathrm{C}$ for $30 \mathrm{~min}$ to get complete lysis of the embryo biopsies and to release RNA. The embryo extract was loaded onto a pre-conditioned purification column and centrifuged to allow for the RNA to bind to the spin column. On-column DNA digestion using RNase-free DNase (Qiagen $\mathrm{GmbH}$ ) was performed to remove any genomic DNA contamination. Following subsequent washing, the RNA was eluted with $12 \mu \mathrm{l}$ RNase-free water.

\section{RNA amplification}

First- and second-strand cDNA synthesis were carried out as described in our previous studies (El-Sayed et al. 2006). Briefly, $1 \mu \mathrm{l}$ of $20 \mu \mathrm{M}$ T7 oligo d(T)21 primer (TCTAGTCGACGGCCAGTGAATTGTAATACGACTCACTATAGG-GCG(T)21) was added to total RNA of embryo biopsies and co-incubated for $3 \mathrm{~min}$ at $70{ }^{\circ} \mathrm{C}$ and placed immediately on ice for $2 \mathrm{~min}$. Eight microliters of RT mix $(1 \times$ first-strand buffer, $0.3 \mathrm{mM}$ dNTP, $0.1 \mathrm{mM}$ DTT, $10 \mathrm{U}$ RNase inhibitor (Promega), and $200 \mathrm{U}$ Superscript II RT (Invitrogen)) were added to the $11 \mu \mathrm{I}$ mRNA sample. The reaction was incubated at $42{ }^{\circ} \mathrm{C}$ for $90 \mathrm{~min}$ and terminated by heating at $75^{\circ} \mathrm{C}$ for $15 \mathrm{~min}$. The second-strand synthesis and global PCR amplification were carried out using degenerated oligonucleotides primer (DOP) and PCR master kit (Roche Diagnosis). For this, $20 \mu \mathrm{l}$ first-strand cDNA product, $40 \mu \mathrm{l}$ of $2 \times$ DOP PCR master mix, $1 \mu$ IOP primer to the final concentration, $1 \mu \mathrm{l}$ of $20 \mu \mathrm{M}$ T7 oligo (dT)21 primer, and $16 \mu \mathrm{l}$ 
water were properly mixed. The reaction was heated at $95{ }^{\circ} \mathrm{C}$ for $5 \mathrm{~min}$ to activate the polymerase, followed by cycle of denaturation at $95{ }^{\circ} \mathrm{C}$ for $30 \mathrm{~s}$ and annealing at $30{ }^{\circ} \mathrm{C}$ for $90 \mathrm{~s}$. Subsequently, the temperature was increased at the rate of $0.2{ }^{\circ} \mathrm{C} / \mathrm{s}$ until it reached $72{ }^{\circ} \mathrm{C}$ and incubated for $3 \mathrm{~min}$ at this temperature. Once the second-strand synthesis was completed, global PCR amplification was continued for the rest of the ten cycles at $94{ }^{\circ} \mathrm{C}$ for $30 \mathrm{~s}, 60{ }^{\circ} \mathrm{C}$ for $30 \mathrm{~s}, 72{ }^{\circ} \mathrm{C}$ for $3 \mathrm{~min}$, and final extension at $72{ }^{\circ} \mathrm{C}$ for $7 \mathrm{~min}$. Ten cycles of amplification were found to be optimum to keep representation of the mRNA population after in vitro transcription (Mamo et al. 2006). The cDNA was purified and used for in vitro transcription using AmpliScribe T7 transcription kit (Epicentre Technologies, Oldendorf, Germany) according to manufacturer's instruction. Briefly, $2 \mu$ of $10 \times$ reaction buffer, $4 \mu \mathrm{dNTP}(100 \mathrm{mM}$ each of ATP, CTP, GTP and UTP), $2 \mu \mathrm{l}$ DTT, and $2 \mu \mathrm{l}$ of T7 RNA polymerase were added to $10 \mu \mathrm{l}$ purified cDNA, mixed well, and incubated at $42{ }^{\circ} \mathrm{C}$ for $3 \mathrm{~h}$. At the end of incubation, $1 \mu \mathrm{l}$ DNase has been added and incubated at $37^{\circ} \mathrm{C}$ for $30 \mathrm{~min}$. Then, the amplified RNA (aRNA) was purified using RNeasy Mini kit (Qiagen) according to the manufacturer's recommendations. Finally, the aRNA was eluted in $30 \mu \mathrm{l}$ RNase-free water.

\section{Aminoallyl labeling and dye coupling}

Aminoallyl labeling and dye coupling was performed as described previously. Briefly, Minimum Information About Microarray Experiments (MIAME) guidelines were adhered to our experimental design. Three independent labeling reactions (including dye-swaps, Cy3, and Cy5) were carried out per aRNA sample pertaining to each biological replicate. Accordingly, $3 \mu \mathrm{g}$ aRNA from each embryo biopsy pool representing each group was used as template in RT incorporating aminomodified dUTPs into the cDNA using the CyScribe PostLabelling Kit (Amersham Biosciences). The aRNA, anchored oligo(dT), and random nanomer primers were co-incubated at $70{ }^{\circ} \mathrm{C}$ for $5 \mathrm{~min}$ followed by incubation for $10 \mathrm{~min}$ at room temperature. Then, $10 \mu \mathrm{l}$ reaction mix (containing $4 \mu \mathrm{l}$ of $5 \times$ first-strand buffer, $2 \mu \mathrm{l}$ of $0.1 \mathrm{M}$ DTT, $1.5 \mu \mathrm{l}$ dNTP mix, $1.5 \mu \mathrm{l}$ aminoallyl dUTP, and $1 \mu$ l CyScript reverse transcriptase) was added to the RNA primer mix and incubated at $42{ }^{\circ} \mathrm{C}$ for $90 \mathrm{~min}$. At the end of this reaction, $2 \mu \mathrm{l}$ of $2.5 \mathrm{M} \mathrm{NaOH}$ was added to hydrolyze any rest of mRNA and incubated at $37^{\circ} \mathrm{C}$ for $15 \mathrm{~min}$. The aminoallyl-labeled cDNA samples were purified using CyScribe GFX purification kit (Amersham Biosciences) after adding $10 \mu \mathrm{l}$ of $2 \mathrm{M}$ HEPES. The purified aminoallyl-labeled cDNA samples were then eluted in $60 \mu \mathrm{l}$ of $0.1 \mathrm{M}$ sodium bicarbonate. The triplicate cDNA samples of each embryo biopsy group were differentially labeled indirectly using $\mathrm{N}$-hydroxysuccinate-derived Cy3 and Cy5 dyes and incubated for $1.5 \mathrm{~h}$ at room temperature in dark. At the end of incubation, non-reacting dyes were quenched by adding $15 \mu \mathrm{l}$ of $4 \mathrm{M}$ hydroxylamine solution (Sigma) and incubated for $15 \mathrm{~min}$ at room temperature in darkness. To avoid variation due to dye coupling, aRNA samples from the same group were labeled reversibly either with Cy3 or with Cy5 for dye-swap hybridizations. The reaction was then purified with CyScribe GFX purification kit (Amersham Biosciences). Samples were finally eluted in $60 \mu$ l elution buffer.

\section{Probe hybridization}

Probe hybridization was performed as described previously (El-Sayed et al. 2006). Briefly, pre-hybridization of the slides was performed by placing the array slides into a corning GAPS II slide container and incubating in warm $\left(55^{\circ} \mathrm{C}\right)$ pre-hybridization buffer $(5 \times$ SSC, $0.1 \%$ SDS (Sigma), and 1\% BSA (Roche)) for $20 \mathrm{~min}$. Following pre-hybridization, slides were rinsed for $1 \mathrm{~min}$ in boiling RNase-free water to denature probes and to wash unbound $\mathrm{CDNA}$ from the slide surface. The slides were immediately immersed in RNase-free water at room temperature and then isopropanol each for $1 \mathrm{~min}$. Then, the slides were dried by centrifugation at $2000 \mathrm{~g}$ (370 r.p.m.) for $2 \mathrm{~min}$.

Hybridization and post-hybridization washes were carried out as described previously (El-Sayed et al. 2006). The samples

Table 5 Details of the primers used for quantitative real-time PCR analysis.

\begin{tabular}{|c|c|c|c|}
\hline Gene name & GenBank accession number & Primer sequences & Product size $(b p)$ \\
\hline S100A10 & NM_174650 & $\begin{array}{l}\text { F: 5'-GGATTTCTGAGCATATGGGACC-3' } \\
\text { R: 5'-GAGCAAGAGGATGCAAGCAATA-3' }\end{array}$ & 131 \\
\hline GAPDH & BC102589 & $\begin{array}{l}\text { F: 5'-ACCCAGAAGACTGTGGATGG-3' } \\
\text { R: } 5^{\prime} \text {-ACGCCTGCTTCACCACCTTC-3' }\end{array}$ & 247 \\
\hline PLAC8 & NM_016619 & $\begin{array}{l}\text { F: 5'-CGGTGTTCCAGAGGTTTTTCC-3' } \\
\text { R: 5'-ACTGACCGTCTGACCGTAGAA-3' }\end{array}$ & 163 \\
\hline KRT8 & $X 12877$ & $\begin{array}{l}\text { F: 5'-CACCAGTTCCAAGCCTGTGG-3' } \\
\text { R: } 5^{\prime} \text {-TCAGGTCTCCTGTGCAGATGC-3' }\end{array}$ & 176 \\
\hline BMP15 & AY304484 & $\begin{array}{l}\text { F: 5'-CTGACGCAAGTGGACACCCTA-3' } \\
\text { R: 5'-GACACACGAAGCGGAGTCGTA-3' }\end{array}$ & 396 \\
\hline HSPD1 & ВC002676 & $\begin{array}{l}\text { F: 5'-ACTGTACTGGCACGCTCTAT-3' } \\
\text { R: 5' }\end{array}$ & 172 \\
\hline RPLPO & AB098748 & $\begin{array}{l}\text { F: 5'-GAATCCCATATCCTCGTCCGA-3' } \\
\text { R: } 5^{\prime} \text {-TTGCTGAAAAGGTCAAGGCCT-3' }\end{array}$ & 162 \\
\hline RGS2 & NM_002923 & $\begin{array}{l}\text { F: 5'-GCAGTTGTAAAGCAGCCACTTG-3' } \\
\text { R: 5'-ATATTGAATTCTGGCTGGCCTG-3' }\end{array}$ & 193 \\
\hline FL405 & AY308069 & $\begin{array}{l}\text { F: 5'-GGGTCCTTTACCCTCTCCAC-3' } \\
\text { R: } 5^{\prime} \text {-CTACGTTGAAGCCCGAGACT-3 } 3^{\prime}\end{array}$ & 169 \\
\hline
\end{tabular}


to be hybridized on specific array were mixed and dried in speedvac (SPD111v-230) and then centrifuged (Savant, Holbrook, NY 11741-4306 USA). Then, the pellet was re-suspended in pre-warmed $\left(42{ }^{\circ} \mathrm{C}\right)$ formamide-based hybridization buffer (15 $\mu$ l hybridization buffer (Amersham Bioscience), $30 \mu \mathrm{l}$ of $100 \%$ formamide and $15 \mu \mathrm{l}$ diethylpyrocarbonate (DEPC) water $(1 \mathrm{ml}$ of $0.1 \%$ diethylpyrocarbonate to $1000 \mathrm{ml}$ distilled water)). To this, $2.5 \mu \mathrm{l}$ yeast tRNA $(4 \mathrm{mg} / \mathrm{ml})$ and $2.5 \mu \mathrm{l}$ Cothuman DNA (1 mg/ml; Invitrogen) were added to avoid nonspecific hybridization. The pellet was denatured at $95{ }^{\circ} \mathrm{C}$ for 5 min, centrifuged briefly, and hybridized to the array. The arrays were covered with glass coverslips (ROTH, Karlsruhe, Germany) and placed and fixed well in the hybridization cassette (TeleChem International, Inc., Sunnyvale, CA, USA). The cassette was incubated in a hybridization chamber (GFL, Dülmen, Germany) at $42{ }^{\circ} \mathrm{C}$ for $16 \mathrm{~h}$. After hybridization, slides were washed twice with $2 \times$ SSC- $0.1 \%$ SDS buffer for 5 min at $42{ }^{\circ} \mathrm{C}$, then once with $1 \times \mathrm{SSC}, 0.2 \times \mathrm{SSC}$, and $0.1 \times \mathrm{SSC}$ for 5 min each at room temperature. Finally, the slides were rinsed with RNA-free water and then with isopropanol for one min each and centrifuged at $2000 \mathrm{~g}$ (370 r.p.m.) for $2 \mathrm{~min}$.

\section{Array scanning and data analysis}

Array scanning and data analysis were performed as described previously (El-Sayed et al. 2006). Briefly, slides were scanned using Axon GenePix 4000B scanner (Axon Instruments, Foster City, CA, USA). The GenePix Pro 4.0 software (Axon Instruments) was used to process the images, to find spots, to integrate robot-spotting files, and finally to create reports of spot intensity data. The LOWESS normalization of microarray data was performed using GPRocessor 2.0a software (http:// bioinformatics.med.yale.edu/group/). The normalized data were used to calculate intensity ratios of all replicates and to obtain one value per clone. Ratios were finally $\log _{2}$ transformed and submitted to significance analysis for microarray (SAM) analysis. Microarray data analysis was performed using SAM - free software developed at Stanford University (http://www-stat.stanford.edu/ tibs/SAM/).

\section{RT-qPCR analysis}

To validate microarray results, eight candidate genes were selected due to their high fold change or because of their differential expression both in this and in our recent study (El-Sayed et al. 2006) for further analysis by RT-qPCR (Table 5). Quantitative analysis of cDNA samples was performed as described previously (El-Sayed et al. 2006) using ABI PRISM 7000 sequence detection system (Applied Biosystems, Foster City, CA, USA). The cDNA was synthesized from independent embryo biopsies of all groups. RT-qPCR was first performed with all samples to test for any variation in the expression of this internal control gene $(G A P D H)$. After confirming that there were no significant differences in the relative abundance of GAPDH between samples, all transcripts were quantified using independent RT-qPCR runs. Standard curves were generated for both the target and the endogenous control genes using serial dilution of plasmid DNA ( $10^{1}$ to $10^{8}$ molecules). The RT-qPCR was performed in $20 \mu \mathrm{l}$ reaction volume containing $10 \mu \mathrm{l}$ iTaq
SYBR Green Supermix with ROX (Bio-Rad). During each RT-qPCR reaction, samples from the same cDNA source were run in duplicate to control the reproducibility of real-time results. A universal thermal cycling parameter $\left(10 \mathrm{~s}\right.$ at $50{ }^{\circ} \mathrm{C}$, $10 \mathrm{~min}$ at $95^{\circ} \mathrm{C}, 15 \mathrm{~s}$ at $95^{\circ} \mathrm{C}$ for 45 cycles, and $60 \mathrm{~s}$ at $60^{\circ} \mathrm{C}$ ) was used to quantify each gene of interest. At the end of the last cycle, dissociation curve was generated by starting the fluorescence acquisition at $60{ }^{\circ} \mathrm{C}$ and taking measurements at every $7 \mathrm{~s}$ interval until the temperature reached $95^{\circ} \mathrm{C}$. Final quantitative analysis was performed using the relative standard curve method, and relative gene abundance of NP and $\mathrm{PL}$ groups were reported as $n$-fold difference compared with the $C D$ group. Since gene expression of $C D$ group served as control, relative expression of genes for $C D$ group was set to 1.0 .

\section{Statistical analysis}

The gene expression analysis for studied genes was performed based on the standard curve method. The relative expression data were analyzed using general linear model (GLM) of the Statistical Analysis System (SAS) software package version 8.0 (SAS Institute, Inc., Cary, NC, USA). Differences in mean values were obtained using ANOVA followed by a multiple pairwise comparison using the Tukey test. Differences of $P<0.05$ were considered as significant.

\section{Declaration of interest}

The authors declare that there is no conflict of interest that could be perceived as prejudicing the impartiality of the research reported.

\section{Funding}

This research did not receive any specific grant from any funding agency in the public, commercial, or not-for-profit sector.

\section{References}

Adjaye J, Herwig R, Herrmann D, Wruck W, Benkahla A, Brink TC, Nowak M, Carnwath JW, Hultschig C, Niemann H et al. 2004 Crossspecies hybridisation of human and bovine orthologous genes on high density cDNA microarrays. BMC Genomics 28 83. (doi:10.1186/14712164-5-83)

Arner ES \& Holmgren A 2000 Physiological functions of thioredoxin and thioredoxin reductase. European Journal of Biochemistry $\mathbf{2 6 7}$ 6102-6109. (doi:10.1046/j.1432-1327.2000.01701.x)

Arrigo AP 1999 Gene expression and the thiol redox state. Free Radical Biology \& Medicine 27 936-944. (doi:10.1016/S0891-5849(99)00175-6)

Ayalon N 1978 A review of embryonic mortality in cattle. Journal of Reproduction and Fertility 54 483-493. (doi:10.1530/jrf.0.0540483)

Baribault H, Price J, Miyai K \& Oshima RG 1993 Mid-gestational lethality in mice lacking keratin 8. Genes and Development 7 1191-1202. (doi:10.1101/gad.7.7a.1191)

Bensaude O, Babinet C, Morange M \& Jacob F 1983 Heat shock proteins, first major products of zygotic gene activity in mouse embryo. Nature 305 331-333. (doi:10.1038/305331a0)

Betts DH \& King WA 2001 Genetic regulation of embryo death and senescence. Theriogenology 55 171-191. (doi:10.1016/S0093691X(00)00453-2) 
Bing YZ, Hirao Y, Takenouchi N, Che LM, Nakamura H, Yodoi J \& Nagai T 2003 Effects of thioredoxin on the preimplantation development of bovine embryos. Theriogenology 59 863-873. (doi:10.1016/S0093691X(02)01158-5)

Blomberg LA, Long EL, Sonstegard TS, Van Tassell CP, Dobrinsky JR \& Zuelke KA 2005 Serial analysis of gene expression during elongation of the peri-implantation porcine trophectoderm (conceptus). Physiological Genomics 20 188-194. (doi:10.1152/physiolgenomics. 00157.2004)

Brison DR \& Schultz RM 1997 Apoptosis during mouse blastocyst formation: evidence for a role for survival factors including transforming growth factor alpha. Biology of Reproduction 56 1088-1096. (doi:10. 1095/biolreprod56.5.1088)

Brulet P, Babinet C, Kemler R \& Jacob F 1980 Monoclonal antibodies against trophectoderm-specific markers during mouse blastocyst formation. PNAS 77 4113-4117. (doi:10.1073/pnas.77.7.4113)

Charpigny G, Reinaud P, Tamby JP, Creminon C \& Guillomots M 1997 Cyclooxygenase-2 unlike cyclooxygenase- 1 is highly expressed in ovine embryos during the implantation period. Biology of Reproduction $\mathbf{5 7}$ 1032-1040. (doi:10.1095/biolreprod57.5.1032)

Clarke FM 1992 Identification of molecules and mechanisms involved in the 'early pregnancy factor' system. Reproduction, Fertility, and Development 4 423-433. (doi:10.1071/RD9920423)

Clarke FM, Orozco C, Perkins AV, Cock I, Tonissen KF, Robins AJ \& Wells JRE 1991 Identification of molecules involved in the 'early pregnancy factor' phenomenon. Journal of Reproduction and Fertility 93 525-539. (doi:10.1530/jrf.0.0930525)

Corcoran D, Rizos D, Fair T, Evans AC \& Lonergan P 2007 Temporal expression of transcripts related to embryo quality in bovine embryos cultured from the two-cell to blastocyst stage in vitro or in vivo. Molecular Reproduction and Development 74 972-977. (doi:10.1002/ mrd.20677)

Di Pasquale E, Beck-Peccoz P \& Persani L 2004 Hypergonadotropic ovarian failure associated with an inherited mutation of human bone morphogenetic protein-15 (BMP15) gene. American Journal of Human Genetics 75 106-111. (doi:10.1086/422103)

Diskin MG \& Sreenan JM 1980 Fertilization and embryonic mortality rates in beef heifersafter artificial insemination. Journal of Reproduction and Fertility 59 463-468. (doi:10.1530/jrf.0.0590463)

Dobson AT, Raja R, Abeyta MJ, Taylor T, Shen S, Haqq C \& Pera RA 2004 The unique transcriptome through day 3 of human preimplantation development. Human Molecular Genetics 13 1461-1470. (doi:10.1093/ hmg/ddh157)

Ebner T, Yaman C, Moser M, Sommergruber M, Polz W \& Tews G 2001 Embryo fragmentation in vitro and its impact on treatment and pregnancy outcome. Fertility and Sterility 76 281-285. (doi:10.1016/S00150282(01)01904-5)

Edwards JL, King WA, Kawarsky SJ \& Ealy AD 2001 Responsiveness of early embryos to environmental insults: potential protective roles of HSP70 and glutathione. Theriogenology 55 209-223. (doi:10.1016/S0093691X(00)00455-6)

El-Sayed A, Hoelker M, Rings F, Salilew D, Jennen D, Tholen E, Sirard MA, Schellander K \& Tesfaye D 2006 Large-scale transcriptional analysis of bovine embryo biopsies in relation to pregnancy success after transfer to recipients. Physiological Genomics 28 84-96. (doi:10.1152/physiolgenomics.00111.2006)

Farin PW, Piedraita JA \& Farin CE 2006 Errors in development of fetuses and placentas from in vitro-produced bovine embryos. Theriogenology 65 178-191. (doi:10.1016/j.theriogenology.2005.09.022)

Galaviz-Hernandez C, Stagg C, de Ridder G, Tanaka TS, Ko MS, Schlessinger D \& Nagaraja R 2003 Plac8 and Plac9, novel placentalenriched genes identified through microarray analysis. Gene 309 81-89. (doi:10.1016/S0378-1119(03)00508-0)

Hesse M, Franz T, Tamai Y, Taketo MM \& Magin TM 2000 Targeted deletion of keratins 18 and 19 leads to trophoblastic fragility and early embryonic lethality. EMBO Journal 19 5060-5070. (doi:10.1093/emboj/19.19.5060)

Hirota K, Matsui M, Iwata S, Nishiyama A, Mori K \& Yodoi J 1997 AP-1 transcriptional activity is regulated by a direct association between thioredoxin and Ref-1. PNAS 94 3633-3638. (doi:10.1073/pnas.94.8.3633)

Hoelker M, Rings F, Lund Q, Ghanem N, Phatsara C, Griese J, Schellander K \& Tesfaye D 2009 Effect of the microenvironment and embryo density on developmental characteristics and gene expression profile of bovine preimplantative embryos cultured in vitro. Reproduction 137 415-425. (doi:10.1530/REP-08-0370)

Huang ZP, Ni H, Yang ZM, Wang J, Tso JK \& Shen QX 2003 Expression of regulator of G-protein signalling protein 2 (RGS2) in the mouse uterus at implantation sites. Reproduction 126 309-316. (doi:10.1530/rep.0. 1260309)

Imakawa K, Chang K \& Christenson RK 2004 Pre-implantation conceptus and maternal uterine communications: molecular events leading to successful implantation. Journal of Reproduction and Development $\mathbf{5 0}$ 155-169. (doi:10.1262/jrd.50.155)

Jackson BW, Grund C, Schmid E, Burki K, Franke WW \& Illmensee K 1980 Formation of cytoskeletal elements during mouse embryogenesis. Intermediate filaments of the cytokeratin type and desmosomes in preimplantation embryos. Differentiation 17 161-179. (doi:10.1111/j. 1432-0436.1980.tb01093.x)

Juengel JL, Hudson NL, Heath DA, Smith P, Reader KL, Lawrence SB, O'Connell AR, Laitinen MP, Cranfield M, Groome NP et al. 2002 Growth differentiation factor 9 and bone morphogenetic protein 15 are essential for ovarian follicular development in sheep. Biology of Reproduction 67 1777-1789. (doi:10.1095/biolreprod.102.007146)

Khosla S, Dean W, Brown D, Reik W \& Feil R 2001 Culture of preimplantation mouse embryos affect fetal development and the expression of imprinted genes. Biology of Reproduction 64 918-926. (doi:10.1095/biolreprod64.3.918)

Khurana NK \& Niemann H 2000 Energy metabolism in preimplantation bovine embryos derived in vitro or in vivo. Biology of Reproduction 62 847-856. (doi:10.1095/biolreprod62.4.847)

Klein C, Bauersachs S, Ulbrich SE, Einspanier R, Meyer HHD, Schmidt SEM, Reichenbach HD, Vermehren M, Sinowatz F, Blum H et al. 2006 Monozygotic twin model reveals novel embryo-induced transcriptome changes of bovine endometrium in the pre-attachment period. Biology of Reproduction 74 253-264. (doi:10.1095/biolreprod.105.046748)

Knijn HM, Wrenzycki C, Hendriksen PJM, Vos PLAM, Zeinstra EC, van der Weijden GC, Niemann H \& Dieleman SJ 2005 In vitro and in vivo culture effects on mRNA expression of genes involved in metabolism and apoptosis in bovine embryos. Reproduction, Fertility, and Development 17 775-784. (doi:10.1071/RD05038)

Kobayashi-Miura M, Nakamura H, Yodoi J \& Shiota K 2002 Thioredoxin, an anti-oxidant protein, protects mouse embryos from oxidative stressinduced developmental anomalies. Free Radical Research 36 949-956. (doi:10.1080/1071576021000006626)

Lazzari G, Wrenzycki C, Herrmann D, Duchi R, Kruip T, Niemann H \& Galli C 2002 Cellular and molecular deviations in bovine in vitroproduced embryos are related to the large offspring syndrome. Biology of Reproduction 67 767-775. (doi:10.1095/biolreprod.102. 004481)

Liu CH, Yang CC, Lin DP, Wu MH \& Tsai KJ 2004 Stored of Hsp72/Hsp73 in germinal vesicle-stage mouse oocytes. Reproduction in Domestic Animals 39 19-24. (doi:10.1046/j.1439-0531.2003.00470.x)

Lopata A, Sibson MC, Enders AC, Bloomfield KL, Gregory MS, Trapani GD, Perkins AV, Tonissen KF \& Clarke FM 2001 Expression and localization of thioredoxin during early implantation in the marmoset monkey. Molecular Human Reproduction 7 1159-1165. (doi:10.1093/molehr/7.12.1159)

Loureiro B, Brad AM \& Hansen PJ 2007 Heat shock and tumor necrosis factor- $\alpha$ induce apoptosis in bovine preimplantation embryos through a caspase-9 dependent mechanism. Reproduction 133 1129-1137. (doi:10.1530/REP-06-0307)

Mamo E, Sargent CA, Affara NA, Tesfaye D, El-Halawany N, Wimmers K, Gilles M, Schellander K \& Ponsuksili S 2006 Transcripts profiles of some developmentally important genes detected in bovine oocytes and in vitro-produced blastocysts using RNA amplification and cDNA microarrays. Reproduction in Domestic Animals 41 527-534. (doi:10.1111/j. 1439-0531.2006.00708.x)

Nonogaki T, Noda Y, Narimoto K, Umaoka Y \& Mori T 1991 Protection from oxidative stress by thioredoxin and superoxide dismutase of mouse embryos fertilized in vitro. Human Reproduction 6 1305-1310.

Nowak-Imialek M, Wrenzycki C, Herrmann D, Lucas-Hahn A, Lagutina I, Lemme E, Lazzari G, Galli C \& Niemann H 2008 Messenger RNA expression patterns of histone-associated genes in bovine preimplantation embryos derived from different origins. Molecular Reproduction and Development 75 731-743. (doi:10.1002/mrd.20816) 
Oshima RG, Howe WE, Klier FG, Adamson ED \& Shevinsky LH 1983 Intermediate filament protein synthesis in preimplantation murine embryos. Developmental Biology 99 447-455. (doi:10.1016/00121606(83)90294-4)

Ozawa M, Nagai T, Fahrudin M, Karja NW, Kaneko H, Noguchi J, Ohnuma K \& Kikuchi K 2006 Addition of glutathione or thioredoxin to culture medium reduces intracellular redox status of porcine IVM/IVF embryos, resulting in improved development to the blastocyst stage. Molecular Reproduction and Development 73 998-1007. (doi:10.1002/ mrd.20533)

Powis G, Gasdaska JR \& Baker A 1997 Redox signaling and the control of cell growth and death. Advances in Pharmacology 38 329-359. (doi:10. 1016/S1054-3589(08)60990-4)

Powis G, Kirkpatrick DL, Angulo M \& Baker A 1998 Thioredoxin redox control of cell growth and death and the effects of inhibitors. ChemicoBiological Interactions 111 23-34. (doi:10.1016/S0009-2797(97)00148-8)

Rizos D, Lonergan P, Ward F, Duffy P \& Boland MP 2002 Consequences of bovine oocyte maturation, fertilization or early embryo development in vitro versus in vivo: implications for blastocyst yield and blastocyst quality. Molecular Reproduction and Development 61 234-248. (doi:10. 1002/mrd.1153)

Salilew-Wondim D, Rings F, Holker M, Gilles M, Jennen D, Tholen E, Havlicek V, Besenfelder U, Sukhorukov VL, Zimmermann U et al. 2007 Dielectrophoretic behavior of in vitro-derived bovine metaphase II oocytes and zygotes and its relation to in vitro embryonic developmental competence and mRNA expression pattern. Reproduction 133 931-946. (doi:10.1530/REP-06-0277)

Salilew-Wondim D, Hölker M, Rings F, Ghanem N, Ulas-Cinar M, Peippo J, Tholen E, Looft C, Schellander K \& Tesfaye D 2010 Bovine pretransfer endometrium and embryo transcriptome fingerprints as predictors of pregnancy success after embryo transfer. Physiological Genomics 42 201-218. (doi:10.1152/physiolgenomics.00047.2010)

Santos F, Zakhartchenko V, Stojkovic M, Peters A, Jenuwein T, Wolf E, Reik W \& Dean W 2003 Epigenetic marking correlates with developmental potential in cloned bovine preimplantation embryos. Current Biology 13 1116-1121. (doi:10.1016/S0960-9822(03)00419-6)

Shao GB, Ding HM, Gong AH \& Xiao DS 2008 Inheritance of histone H3 methylation in reprogramming of somatic nuclei following nuclear transfer. Journal of Reproduction and Development 54 233-238. (doi:10. 1262/jrd.19173)
Smith SL, Everts RE, Tian XC, Du F, Sung LY, Rodriguez-Zas SL, Jeong BS, Renard JP, Lewin HA \& Yang X 2005 Global gene expression profiles reveal significant nuclear reprogramming by the blastocyst stage after cloning. PNAS 102 17582-17587. (doi:10.1073/pnas.0508952102)

Smith SL, Everts RE, Sung LY, Du F, Page RL, Henderson B, RodriguezZas SL, Nedambale TL, Renard JP, Lewin HA et al. 2009 Gene expression profiling of single bovine embryos uncovers significant effects of in vitro maturation, fertilization and culture. Molecular Reproduction and Development 76 38-47. (doi:10.1002/mrd.20927)

Snabes MC \& Harper MJK 1984 Site of action of indomethacin on implantation in the rabbit. Journal of Reproduction and Fertility 71 89-98. (doi:10.1530/jrf.0.0710089)

Soto P, Natzke RP \& Hansen PJ 2003 Actions of tumor necrosis factor- $\alpha$ on oocyte maturation and embryonic development in cattle. American Journal of Reproductive Immunology 50 380-388. (doi:10.1034/j.16000897.2003.00101.x)

Watson AJ, Westhusin ME, De Sousa PA, Betts DH \& Barcroft LC 1999 Gene expression regulating blastocyst formation. Theriogenology $\mathbf{5 1}$ 117-133. (doi:10.1016/S0093-691X(98)00236-2)

Wu YT, Tang L, Cai J, Lu XE, Xu J, Zhu XM, Luo Q \& Huang HF 2007 High bone morphogenetic protein-15 level in follicular fluid is associated with high quality oocyte and subsequent embryonic development. Human Reproduction 22 1526-1531. (doi:10.1093/ humrep/dem029)

Yamagishi N, Saito Y, Ishihara K \& Hatayama T 2002 Enhancement of oxidative stress-induced apoptosis by Hsp105alpha in mouse embryonal F9 cells. European Journal of Biochemistry 269 4143-4151. (doi:10. 1046/j.1432-1033.2002.03109.x)

Zmijewski JW, Song L, Harkins L, Cobbs CS \& Jope RS 2001 Oxidative stress and heat shock stimulate RGS2 expression in 1321N1 astrocytoma cells. Archives of Biochemistry and Biophysics 392 192-196. (doi:10.1006/ abbi.2001.2430)

Received 22 November 2010

First decision 5 January 2011

Revised manuscript received 13 July 2011

Accepted 28 July 2011 